\title{
Antibacterial activity of leaf extracts of some selected traditional medicinal plants of Uttarakhand, North East India
}

\author{
Suneel K umar Singh*, R itu Vishnoi, G ulshan K umar Dhingra and K unal K ishor ${ }^{2}$ \\ Department of Biotechnology, Modern Institute of Technology, Dhalwala, Rishikesh - 249201 (Uttarakhand), INDIA \\ 'Department of Botany, Govt. P.G. College, Uttarkashi (Uttarakhand), INDIA \\ ${ }^{2}$ Department of Microbiology, S.G.R.R. (ITS), Dehradun (Uttarakhand), INDIA \\ *Corresponding author. E-mail: drsuneelkumarsingh@gmail.com
}

Abstract: Screenings of methanolic leaf extracts of nine medicinal plants (Cotinus coggygria, Adhatoda vesica, Argemone mexicana, Zanthoxylum armatum, Berberis asiatica, Corissa opaca, Euphorbia hirta, Cassio fistula and Ricinus communis), belonging to selected areas of Uttarakhand, were tested against seven bacterial strains (Bacillus subtilis, Staphylococcus aureus, Escherichia coli, Enterobactor aerogenes, Klebsiella pneumoniae, Proteus vulgaris and Pseudomonas aeruginosa) by disc diffusion method. Leaf extracts of R. communis, B. asiatica and C. opaca showed high $(13-23)$ effect on all the bacterial strains while E. hirta, Z. armatum and A. vesica exhibits minimum $(6-15)$ effects. Remaining leaf extracts of plants were found moderately $(10-19)$ effective.

Keywords: Antibacterial activity, Medicinal plants, Methanol extracts

\section{INTRODUCTION}

The effects of plant extracts on different bacteria have been studied from time to time (Hoffman et al., 2004; Jigma et al. 2005; Srinivasan et al. 2005; Kumar, 2006; Nair and Chanda, 2006; Panthi and Chaudhary, 2006; Uniyal, et al. 2006; Singh et al. 2007a,b; Ahsan et al., 2009 and Osho and Adetunji, 2010). Now-a-days, herbal drugs are prescribed widely even when their biologically active compounds are unknown because of their effectiveness, minimal side effects in clinical experience and relatively low cost. Many of plants have been used traditionally in India. In case of Uttarakhand (north east part of India), many plants from high altitude are still to be tested. However, these plants are in use of ailments by villagers. Keeping this view in mind, leaves of nine easily available medicinal plants (Cotinus coggygria, Adhatoda vesica, Argemone mexicana, Zanthoxylum armatum, Berberis asiatica, Corissa opaca, Euphorbia hirta, Cassio fistula and Ricinus communis) collected from different parts of Uttarakhand, were selected for antimicrobial activity against seven bacteria namely Staphylococcus aureus, Escherichia coli, Enterobactor aerogenes, Klebsiella pneumoniae, Pseudomonas aeruginosa, Proteus vulgaris and Bacillus subtilis.

\section{MATERIALS AND METHODS}

Fresh leaves from healthy plants (Cotinus coggygria, Adhatoda vesica, Argemone mexicana, Zanthoxylum armatum, Berberis asiatica, Corissa opaca, Euphorbia hirta, Cassio fistula and Ricinus communis) have been collected from different study areas Srinagar, Kotdwara, ISSN : 0974-9411 (Print), 2231-5209 (Online) All Rights Reserved ๑ Ap
Pauri, Tehri, Chamoli and Uttarkashi) of Uttarakhand due to availability of these plants in hilly areas. These all listed areas are located above 500 mean sea levels (MSL) and also floral specific. The leaves of all the nine medicinal plants were plucked/detached, washed thrice in running tap water, dried away from direct sunlight in the shade place under room temperature, crushed to coarse powder in electric grinder and used for further studies.

Fifteen gram of the dried and powdered plant material (leaves) was extracted with $250 \mathrm{ml}$ methanol by continuous hot extraction using Soxhlet apparatus for 8 hours. The extract was filtered in Whatman filter paper no. 1 , concentrated by removing the solvent and then dried on rotovap. The residue was kept in sample tubes in refrigerator for further processes. Five Gram - negative (Escherichia coli, Enterobacter aerogenes, Protues vulgaris, Pseudomonas aeruginosa and Klebsiella pneumoniae) and two Gram - positive (Bacillus subtilis and Staphylococcus aureus) bacteria strains were commercially purchased from Bangalore Genei and maintained at laboratory conditions under $37 \pm 2^{\circ} \mathrm{C}$ (Table 1). Antibacterial Streptomycin disc of the concentration of $30 \mu \mathrm{g} / \mathrm{ml}$ was used as a standard. Nutrient broth were used and prepared in distilled de-ionized water. The prepared media (Singh et al. 2007a, b) were autoclaved at $15 \mathrm{lbs}$ per square inch (PSI) pressure at $121^{\circ} \mathrm{C}$ for 20 minutes. Plants, species-wise and part-wise extract (10 $\mu \mathrm{g}, 20 \mu \mathrm{g}$ and $1 \mathrm{~g} / \mathrm{ml}$ ) were suspended in $1000 \mathrm{ml}$ of dimethyl sulphoxide (DMSO) in a conical flask. The suspended solution was then heated on a water bath to dissolve the medium completely. The test organisms were 
maintained on slants of medium and transferred to a fresh slant once in a week. The slant was incubated at $37^{\circ} \mathrm{C}$ for $24 \mathrm{hrs}$. Using $3 \mathrm{ml}$ of saline solution, the organisms were washed from the agar slant on to a large agar surface (medium) and incubated for $24 \mathrm{hrs}$ at $37^{\circ} \mathrm{C}$. The growth from the nutrient surface was washed using $50 \mathrm{ml}$ of distilled water. The amount of suspension to be added to each $100 \mathrm{ml}$ nutrient broth was determined by use of test broth. The test organisms were stored under refrigeration. The antimicrobial activity of soluble and insoluble compounds is normally investigated using the standard methods like disc diffusion technique (Rios et al., 1988; Bauer etal., 1996). Serial dilutions of the agent are prepared in a suitable broth or agar medium and a standard inoculum of the test organism is added. The culture to be examined over the surface of paper discs ( $4 \mathrm{~mm}$ in size) individually impregnated with antibiotic is spaced evenly over the inoculated plate. Antibiotic diffuses outwards from each disc into the surrounding media and produces a diminishing gradient of concentration. On incubation, the bacteria grow on areas of the plate except those around the standard to which they are sensitive. The width of the zone of inhibition is a rough measure of the degree of sensitivity to the test organisms. A highly standardized version of the discdiffusion method (the Bauer-Kirby test) is very popular in different countries. The zone of inhibition was calculated by measuring the minimum dimension of the zone of no bacterial growth around the disc. An average of three independent determinations was recorded.

\section{RESULTS}

The results of antimicrobial activity of different concentrations of selected plants on different bacteria have been shown in Tables 1,2 and 3. The methanol extracts of leaves of R. communis, B. asiatica and C. opaca exhibited high inhibitory effects on $S$. aureus, K. pneumoniae, E. coli, B. subtilis and P. vulgaris in all the concentration. C. coggygria, A. mexicana and $C$. fistula showed moderate impact on all the bacterial strain while $E$. hirta, $Z$. armatum and $A$. vesica were found to have lower affect or least affect on all the strains. Concentration of $10 \mu \mathrm{g} / \mathrm{ml}$ of leaves extract showed various zone of inhibition in different plants and bacterial strains ( 6 - 9 very low; 10 - 12 moderate and 13 - 16 very high). Similarly, the concentrations of $20 \mu \mathrm{g} / \mathrm{ml}$ showed more or less similar results $(9-12$ very low; 13 - 16 moderate and $17-19$ very high). Concentration of $1 \mathrm{~g} / \mathrm{ml}$ of same extract affected all the bacterial strain (13 - 15 very low; 16 - 19 moderate and 20-23 very high). Thus, higher concentration checked the growth of all the bacterial strains (Table 3 ).

\section{DISCUSSION}

A number of workers have approved that medicinal plants

Table 1. Showing antimicrobial screening of leaves of the plants interms of average one of inhibition $(10 \mathrm{~g} / \mathrm{ml})[+++$ very high; ++ moderate; + low].

\begin{tabular}{|c|c|c|c|c|c|c|c|c|c|}
\hline \multirow{2}{*}{$\begin{array}{l}\text { S. } \\
\text { No. }\end{array}$} & \multirow[t]{2}{*}{ Name of the plants } & \multicolumn{7}{|c|}{ Aver age zone of inhibitions ( $\mathrm{mm}$ ) from best of three } & \multirow{2}{*}{$\begin{array}{l}\text { Standard } \\
30 \mu \mathrm{g} / \mathrm{ml}\end{array}$} \\
\hline & & B. S. & S. a. & K.p. & P. V. & E. C. & E. a. & P. a. & \\
\hline 1. & C. coggygria & ++ & ++ & ++ & ++ & ++ & ++ & ++ & 22 \\
\hline 2. & A. vasica & + & + & + & + & + & + & + & 20 \\
\hline 3. & A. mexicana & ++ & ++ & ++ & ++ & ++ & ++ & ++ & 20 \\
\hline 4. & Z. armatum & + & + & + & + & + & + & + & 20 \\
\hline 5. & Carissa opaca & +++ & +++ & +++ & +++ & +++ & ++ & ++ & 20 \\
\hline 6. & B. asiatica & +++ & +++ & +++ & +++ & +++ & ++ & ++ & 22 \\
\hline 7. & E. hirta & & & & & & & & 20 \\
\hline 8. & R. communis & +++ & +++ & +++ & +++ & +++ & ++ & ++ & 20 \\
\hline 9. & C. fistula & ++ & ++ & ++ & ++ & ++ & ++ & ++ & 20 \\
\hline
\end{tabular}

Table 2. Showing antimicrobial screening of leaves of the plants interms of average one of inhibition $(20 \mathrm{~g} / \mathrm{ml})[+++$ very high; ++ moderate; + low].

\begin{tabular}{|c|c|c|c|c|c|c|c|c|c|}
\hline \multirow{2}{*}{$\begin{array}{l}\text { S. } \\
\text { No. }\end{array}$} & \multirow[t]{2}{*}{ Name of the plants } & \multicolumn{7}{|c|}{ A ver age zone of inhibitions ( $\mathrm{mm}$ ) from best of three } & \multirow{2}{*}{$\begin{array}{c}\text { Standard } \\
30 \mu \mathrm{g} / \mathrm{ml}\end{array}$} \\
\hline & & B.S. & S. a. & K.p. & P.V. & E.C. & E.a. & P.a. & \\
\hline 1. & C. coggygria & ++ & ++ & ++ & ++ & ++ & ++ & ++ & 24 \\
\hline 2. & A. vasica & + & + & + & + & + & + & + & 22 \\
\hline 3. & A. mexicana & ++ & ++ & ++ & ++ & ++ & ++ & ++ & 22 \\
\hline 4. & Z. armatum & + & + & + & + & + & + & + & 22 \\
\hline 5. & C. ораса & +++ & +++ & +++ & +++ & +++ & ++ & ++ & 22 \\
\hline 6. & B. asiatica & +++ & +++ & +++ & +++ & +++ & ++ & ++ & 24 \\
\hline 7. & E. hirta & & & & & & & & 22 \\
\hline 8. & R. communis & +++ & +++ & +++ & +++ & +++ & ++ & ++ & 22 \\
\hline 9. & C. fistula & ++ & ++ & ++ & ++ & ++ & ++ & ++ & 22 \\
\hline
\end{tabular}


Table 3. Showing antimicrobial screening of leaves ofthe plants interms of average one of inhibition (1 g/ml) [+++ very high; ++ moderate; + low].

\begin{tabular}{|c|c|c|c|c|c|c|c|c|c|}
\hline \multirow{2}{*}{$\begin{array}{l}\text { S. } \\
\text { No. }\end{array}$} & \multirow[t]{2}{*}{ Name of the plants } & \multicolumn{7}{|c|}{ A ver age zone of inhibitions (mm) from best of three } & \multirow{2}{*}{$\begin{array}{l}\text { Standard } \\
30 \mu \mathrm{g} / \mathrm{ml}\end{array}$} \\
\hline & & B. S. & S. a. & K.p. & P. V. & E.C. & E. a. & P. a. & \\
\hline 1. & C. coggygria & ++ & ++ & ++ & ++ & ++ & ++ & ++ & 26 \\
\hline 2. & A. vasica & + & + & + & + & + & + & + & 24 \\
\hline 3. & A. mexicana & ++ & ++ & ++ & ++ & ++ & ++ & ++ & 24 \\
\hline 4. & Z. armatum & + & + & + & + & + & + & + & 24 \\
\hline 5. & C. ораса & +++ & +++ & +++ & +++ & +++ & ++ & ++ & 24 \\
\hline 6. & B. asiatica & +++ & +++ & +++ & +++ & +++ & ++ & ++ & 26 \\
\hline 7. & E. hirta & & & & & & & & 24 \\
\hline 8. & R. communis & +++ & +++ & +++ & +++ & +++ & ++ & ++ & 24 \\
\hline 9. & C. fistula & ++ & ++ & ++ & ++ & ++ & ++ & ++ & 24 \\
\hline
\end{tabular}

Abbreviations: B. S. (Bacillus subtilis), S. a. (Staphylococcus aureus), K. b. (Klebsiella pneumonia), P. v. (Proteus vulgaris), E. s. ( Escherichia coli), E.a. ( Enterobactor aerogenes), P. s. (Pseudomonas aeruginosa)

represent a rich source of antimicrobial agents. Plants are used medicinally in different countries and are a source of many potent and powerful drugs. A wide range of medicinal plant parts are being used for extract as raw drug and they possess varied medicinal properties. The different parts are roots, stems, flowers, fruits, leaves, twigs exudates and modified plant organs. The zone of inhibition produced by the test organisms indicated their susceptibility to the plant extracts; it was observed that the zones of inhibition varies from one organisms to another and from one plant part extract to another. The present study is the preliminary reports on testing of leaves extracts of different medicinal plant species occurring in Uttarakhand. Out of nine plant species, only three (C. opaca, B. asiatica and R. cummunis) were found very effective on two gram positive (B. subtilis and $S$. aureus) and three gram negative (E. coli, P. vulgaris and $K$. pneumoniae) bacterial strain, while $E$. aerogenes and $P$. aeruginosa exhibited moderate affect. Similarly, leave extract of C. coggygria, A. mexicana and C. fistula moderately inhibited all the seven bacterial strain. E. hirta does not showed any effect in all the concentration for any bacteria. Various workers have already shown that gram positive bacteria are more susceptible towards plants extracts as compared to gram negative bacteria. In the present study, similar trend bas been noted as both the gram positive bacteria were affected by leave extracts of all the eight plant species. Bhattacharjee et al. (2006), Ahsan et al. (2009) Rahman et al. (2009); Osho and Adetunji (2010) have reported that A. mexicana is very effective against several bacterial strains, but in our study extract of A. mexicana showed moderate effect. Likewise, Cowan (1999) reported that extract of R. communis checked the growth of bacteria which is further supported by present study. However, before coming to conclusive statement, further studies like gas chromatography - mass spectroscopy (GCMS), infrared (IR) and nuclear magnetic resonance (NMR) essential for identification of present active constituents, responsible for the observed activity are under consideration to perform. Perfect prediction of antibacterial activity of botanical compounds from plant material is largely dependent on the type of solvent used in the extraction procedure. Methanol extracts was found to much better in present investigation. Crude extracts and their interaction with different active fractions of the plant need to be explored the exact mechanism of the interaction among the active phyto-constituents. Similarly, the efficacy of crude extracts preparation required to be studied in more detail.

\section{ACKNOW LEDGEMENTS}

The authors are thankful to the Director (Modern Institute of Technology, Rishikesh) for providing the laboratory facilities; to Dr. G. S. Rajwar (Deputy Director, Higher Education, Uttarakhand) and to Director, Forest Research Institute (F.R.I.) and Botanical Survey of India (B.S.I.), Dehradun (Uttarakhand), for identification of plants.

\section{REFERENCES}

Ahsan, M.R., Islam, K.M., Haque, M.E. and Mossaddik, M.A. (2009). In vitr 0 antibacterial screening and toxicity study of some different medicinal plants. World J. Agric. Sci., 5(5): 617-621.

Bauer, R.W., Kirby, M.D.K., Sherris, J.C. and Turck, M. (1996). Antibiotic susceptibility testing by standard single disc diffusion method. Am. J. Clin. Pathol., $45: 493$ - 496.

Bhattacharjee, I., Chatterjee, S.K., Chatterjee, S. and Chandra, G. (2006). Antibacterial potentiality of argemone Mexicana solvent extracts against some pathogenic bacteria. M emorias do Instituto O swaldo Cruz, 101(6): 645-648.

Cowan, M.M. (1999). Plant products as antimicrobial agents. Clinical Microb. Rev., 12: 564-582.

Hoffman, B.R., Delas, A.H., Blanco, K., Wiederhold, N., Lewis, R.E. and Williams, L. (2004). Screening of antibacterial and antifungal activities of ten medicinal plants from Ghana. Pharmaceutical Biol., 42(1): 13-17.

Jigma, P., Rathish, N. and Sumitra, C. (2005). Preliminary screening of some folklore medicinal plants from western India for potential antimicrobial activity. Indian J. Pharmacol., 37(6): 408-409. 
Kumar, N. (2006). Medicinal plants: future source of pesticides. Asian J Microb, Biotech \& Env. Sciences, 8(1): $57-59$.

Rahman, M.M., Jahangir, Alam M., Sharmin, S.A., Rahman, M.M., Rahman, A. and Alam, M.F. (2009). In vitro antibacterial activity of Argemone Mexicana L. (Papaveraceae). CM U J . Nat. Sci., 8(1): 77-84.

Nair, R. and Chanda, S. (2006). Activity of some medicinal plants against certain pathogenic bacteria strains. Indian J . Pharmacol., 38(2): 142-144.

Osho, A. and Adetunji, T. (2010). Antimicrobial activity of the essential oil of Argemone mexicana Linn. J. Med. Plants. Res., 4(1): 19-22.

Panthi, M.P. and Chaudhary, R.P. (2006). Antimicrobial activity of some selected folklore medicinal plants from west Nepal. Scientific World, 4(4): 16-21.

Rahman, M.M., Alam, M.J., Sharmin, S.A., Rahman, M.M., Rahman, A. and Alam, M.F. (2009). In vitro antibacterial activity of Argemone mexicana L. (Papaveraceae). CMU . J . Nat. Sci., 8(1): 77-84.
Rios, J.L., Recio, M.C. and Villar, A. (1988). Screening methods for natural products with antibacterial activity: a review of the literature. J . E thanopharmacol., 23: 127-149.

Singh, M., Srivastava, S. and Rawat, A.K.S. (2007a). Antimicrobial activities of Indian Berberis species. Fitoterapia, 78: 574-576.

Singh, S.K., Kumar, M., Kohli, S., and Rajwar, G.S. (2007b). Screening of methanolic leaf extracts of Eupatorium adenophorum against different bacteria under in vitro condition. Annals of M ed. Entomol., 16(1 \& 2): 1-6.

Srinivasan, K., Dheen, M.A.N., Perumal, G., Mohanasundari, C. and Natarajan, D. (2005). Screening of methanolic leaf extracts of some medicinal plants against pathogenic bacteria. Ad. Plant Sci., 18(II): 605-607.

Uniyal, S.K., Singh, K.N., Jamwal, P. and Lal, B. (2006). Traditional use of medicinal plants among the tribal communities of Chhota Bhangal, Western Himalayan. J . E thnobiol. Ethnomed., 2: 1-14. 